meist unter Verwendung transossärer Lengemann-Naht versorgt werden. 6mal wurde eine Plastik nach Strandell-Böhler durchgeführt (4mal mit Sehne, $2 \mathrm{mal} \mathrm{mit} \mathrm{Lyodura),} 1 \mathrm{mal}$ nach Witt (alter volarer Kapselriß). Häufigste postoperativ geklagte Beschwerde war eine leichte Beugehemmung.

Schlïsselwörter: Kapselbandverletzung - Daumengrundgelenk - Diagnostik - Therapie.

252. H.-U. Langendorff, H. Schöttle, H. Schöntag, Homburg: Konservative and operative Therapie bei Frakturen der Mittelhand und der Finger.

Manuskript nicht eingegangen

\title{
253. Bericht über 320 Frakturen der Metacarpalknochen
}

\author{
P. Stanković, B. Junghans, Th. Tiling und A. Schmid \\ Klinik und Poliklinik für Allgemeinschirurgie der Universität Göttingen, Robert-Koch-Straße 40, \\ D-3400 Göttingen
}

\section{Report on 320 Fractures of Metacarpal Bones}

\begin{abstract}
Summary. Fifty percent of all fractures are of the fifth metacarpal bone, particularly the subcapital type. They can be divided into four zones: peripheral articular fracture, subcapital type, shaft fracture and central articular fracture, if exact repositioning can be achieved with minimal effort (e.g. percutaneous fixation with Kirschner wires), the hand may remain in the resting position in a cast for 3 or 4 weeks. The most frequent complications after conservative treatment are shortening and rotatory faults with a restriction of movement. Used in these methods of osteosynthesis are Kirschner wires, screws, plates, external fixation and osteoplasty.
\end{abstract}

Key words: Metacarpal fractures - Treatment - Complications.

Zusammenfassung. $50 \%$ aller Brüche entfallen auf den 5 . Mittelhandknochen - vor allem auf den subcapitulären Typ. Einteilung in 4 Zonen - periphere Gelenkfraktur, subcapituläre, Schaft und zentrale Gelenkfraktur. War eine einwandfreie Reposition erreicht worden und gelang es, dieses Ergebnis mit einem minimalen Aufwand zu sichern (z. B. durch die percutane Spickung mit Kirschner-Draht), so war eine 3 bis 4wöchige Ruhestellung der Hand zumutbar. Die häufigsten Komplikationen nach konservativer Therapie waren die Verkürzungen und Rotationsfehler mit Bewegungseinschränkung. Als Osteosyntheseverfahren kamen Kirschner-Drähte, Schrauben, Platten, Fixateur externe und Osteoplastiken zur Anwendung.

Schliisselwörter: Metacarpalfrakturen - Behandlung - Komplikationen.

\section{Indikation und Ergebnisse von Radiuskorrekturoperationen}

\author{
K. Wilhelm
}

Chirurgische Universitätsklinik Innenstadt, Nußbaumstraße 20, D-8000 München 2

\section{Indication and Results of Correction of Malunion in Radius Fractures}

Summary. Post-traumatic malunion usually results from incorrect treatment of a Colles or Smith fracture. Chronic pains, restricted motion and lack of strength can be avoided and the cosmetic appearance of the hand improved, by restoration of the functional anatomy of the wrist. The mal-lignment is corrected by open-wedge osteotomy of the distal end of the radius. A small iliac cortico-cancellus bone graft is inserted at the osteotomy site. By using this technique it is usually possible to avoid the additional resection of the distal ulna. The surgical approach, dorsal or volar, is determined by the type of dislocation. The small T-plate offers a stable fixation. The results are illustrated by 41 cases.

Key words: Radius fracture - Malunion - Operative correction.

Zusammenfassung. Die posttraumatische Fehlstellung am distalen Radius stellt eine häufige Komplikation nach Fraktur dar. Chronische Beschwerden, eingeschränkte Gelenkfunktion, Kraftverlust, kosmetische Gesichtspunkte können Anlaß zu einer Verbesserung sein. Das Prinzip der Korrekturoperation besteht in einer 